\title{
Glyphosate concentration and phytotoxicity in Lactuca sativa Buttercrunch
}

\section{Concentrações de glifosato e fitotoxicidade em Lactuca sativa Buttercrunch}

\author{
Thaís Agda Rodrigues da Cruz Primo' \\ Júlia Nercolini Göde" \\ Mariana Gomes Oliveira"II \\ Taciana Furtado Ribeiro'v \\ Lucas de Bona Sartorv \\ Renata Bulling Magrovi \\ Everton Skoronski ${ }^{\mathrm{VII}}$
}

\begin{abstract}
Agrochemicals, also known as agrotoxics or pesticides, have been widely used to control the proliferation of pests and weeds in agricultural crops to ensure high planting productivity. Among the most used pesticides in the world is the herbicide glyphosate ( $\mathrm{N}$-(phosphonomethyl) glycine), because it proves effective for controlling the annual and perennial growth of weeds in agriculture, forestry, urban areas, and domestic gardens. However, the spraying of this compound on a large scale has caused concern, since it accumulates in the topsoil and can generate negative environmental impacts and damage to human health, as it has toxic potential. Given the above, this study evaluated the phytotoxicity of agrochemical solutions glyphosate in different concentrations for the lettuce species Lactuca sativa Buttercrunch, considering number of germinated seeds, stem length, and root length as parameters of analysis. The concentrations of glyphosate tested were $0.001 \mathrm{mg} . \mathrm{L}-1 ; 0.1 \mathrm{mg} . \mathrm{L}-1 ; 0.5 \mathrm{mg}$. L-1; $1 \mathrm{mg}$. L-1 and $20 \mathrm{mg}$. L- 1 . The trial followed the procedures described by the United States Environmental Protection Agency. For the statistical analysis, were considered the number of germinated seeds of each treatment and the length of the roots and stem of each of the germinated seeds, which were inserted into equations for the definition of the percentage parameters of Germination Effect (\%GE), Root Growth Inhibition (\%RGI) and Germination Index (\%GI). Analysis of variance (ANOVA) was performed to test for statistically significant differences among the groups and compared by applying the Tukey Test at the level of $5 \%$ significance. The results revealed that there was $62.62 \% \mathrm{RGI}$ and a $\mathrm{Gl}$ of only $0.37 \%$ in treatment with glyphosate solution with concentration of $20 \mathrm{mg}$. L-1, indicating that high concentrations of the herbicide have toxic effects for the growth of lettuce species Lactuca sativa Buttercrunch. Only the concentration of 20 mg. L-1 obtained a significant difference in relation to the other concentrations evaluated, including the control treatment for the variable "root growth". Thus, for future work it is recommended that glyphosate solutions with concentrations between 1 and $20 \mathrm{mg}$. L-1 be evaluated and tested for phytotoxicity, cytotoxicity and genotoxicity.
\end{abstract}

Keywords: Agrochemical; Toxicity; N-(phosphonomethyl) glycine.

\footnotetext{
'Universidade do Estado de Santa Catarina, Lages, SC, Brazil - thaisagdarcp@gmail.com.

"Universidade do Estado de Santa Catarina, Lages, SC, Brazil - julianercolini@hotmail.com.

III Universidade do Estado de Santa Catarina, Lages, SC, Brazil - marianagomes.udesc@gmail.com.

IV Universidade do Estado de Santa Catarina, Lages, SC, Brazil - taciana-furtado@hotmail.com.

v Universidade do Estado de Santa Catarina, Lages, SC, Brazil - lbs_bona@hotmail.com.

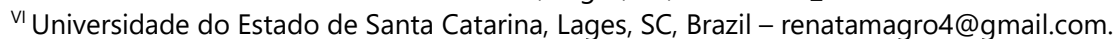

VII Universidade do Estado de Santa Catarina, Lages, SC, Brazil-everton.skoronski@udesc.br.
} 


\section{Resumo}

Os agroquímicos, também conhecidos como agrotóxicos ou pesticidas, têm sido amplamente utilizados no controle da proliferação de pragas e ervas daninhas nos cultivos agrícolas para garantir uma alta produtividade do plantio. Dentre os pesticidas mais utilizados do mundo está o herbicida glifosato ( $\mathrm{N}$-(fosfonometil) glicina), pois se mostra eficaz para o controle do crescimento anual e perene de ervas daninhas na agricultura, silvicultura, áreas urbanas e jardins domésticos. Contudo, a pulverização deste composto em larga escala tem causado preocupação, uma vez que se acumula na camada superior do solo e pode gerar impactos ambientais negativos e danos à saúde humana, já que possui potencial tóxico. Diante do exposto, este estudo avaliou a fitotoxicidade de soluções do agroquímico glifosato em diferentes concentrações para a espécie de alface Lactuca sativa Buttercrunch, levando-se em conta os parâmetros número de sementes germinadas, comprimento do caule e o comprimento da raiz. As concentrações de glisofato testadas foram de 0,001 mg.L1; 0,1 mg.L-1; 0,5 mg.L-1; 1 mg.L-1 e 20 mg.L-1; e o ensaio seguiu os procedimentos descritos pela Agência de Proteção Ambiental dos Estados Unidos. Para a análise estatística, considerou-se o número de sementes germinadas de cada tratamento e o comprimento das raízes e do caule de cada uma das sementes germinadas, as quais foram inseridos em equações para a definição dos parâmetros percentuais de Efeito de Germinação (\%EG), Inibição do Crescimento da Raiz (\%ICR) e Índice de Germinação (\%IG). Os resultados obtidos foram submetidos à análise de variância (ANOVA) e comparados por meio da aplicação do Teste de Tukey ao nível de $5 \%$ de significância. Os resultados revelaram que houve $62,62 \%$ de inibição do crescimento e um índice de germinação de apenas $0,37 \%$ no tratamento com a solução de glifosato com concentração de 20 mg.L-1, indicando que altas concentrações do herbicida possuem efeitos tóxicos para o crescimento da espécie de alface L. sativa Buttercrunch. Apenas a concentração de $20 \mathrm{mg} . \mathrm{L}-1$ obteve diferença significativas em relação às demais concentrações avaliadas, incluindo o tratamento controle para a variável "crescimento da raiz". Deste modo, para trabalhos futuros recomenda-se que soluções de glifosato com concentrações entre 1 e 20 mg.L1 sejam avaliadas e testadas quanto a fitotoxicidade, citotoxicidade e a genotoxicidade.

Palavras-Chave: Agroquímico; Toxicidade; N-(fosfonometil) glicina.

\section{Introduction}

Compounds with functionality to protect agricultural crops or plants from pests or weeds are known as pesticides (ABDELHAMEED et al. 2018). Pesticides have been widely applied in agriculture to ensure high planting productivity (QI et al. 2008). The classification of this compound is carried out mainly in relation to the type of pest that aims to control. According to their action on insects, weeds and fungi, the pesticides are classified into four categories, such as insecticides, herbicides, fungicides, and bactericides (DEBNATH et al. 2019). The organic constituents of agrotoxics have functional attributions that vary according to the group by which they are classified, being these organophosphates, organochlorinated, carbamates and pyrethroids (KONSTANTINOU et al. 2006). As pesticides are biologically active, these can exhibit high toxicity, even when they are present in minimal concentrations (MAURYA; YADAV, 2014). 
Pesticides are applied by aerial dispersion, therefore, the cross-border movement of this compound leads to contamination in areas far from the application point, factor that hinders the monitoring and control of the substance when present in the environment (AKTAR et al. 2009). Large-scale spraying of pesticides pollutes the soil, water sources, plants and living beings, which can cause potential damage to the environment and human health (ZHANG et al. 2019). The intensive and indiscriminate use of pesticides can induce cancerous diseases, reproductive disorders, Parkinson's disease and genetic diseases in humans and animals (DEBNATH et al. 2019).

Among the widely known herbicides, glyphosate ( $\mathrm{N}$-(phosphonomethyl) glycine) is a phosphonate compound whose chemical structure has a phosphorus-carbon (C-P) bond, as illustrated in Figure 1. Considered as the most widely used pesticide in the world, glyphosate is mainly applied to control the annual and perennial growth of weeds in agriculture, forestry, urban areas, and domestic gardens (MORAES, 2019). The development of glyphosate accidentally started in 1950 when Dr. Henri Martin from the Swiss pharmaceutical company (Cliag) synthesized the glyphosate molecule. However, it was John E. Franz from the American Monsanto Company, who conducted the initial tests with the herbicide, making it a commercial product in 1974 (DUKE; POWLES, 2008).

Figure 1 - Chemical structure of glyphosate ( $\mathrm{N}$-(phosphonomethyl) glycine)

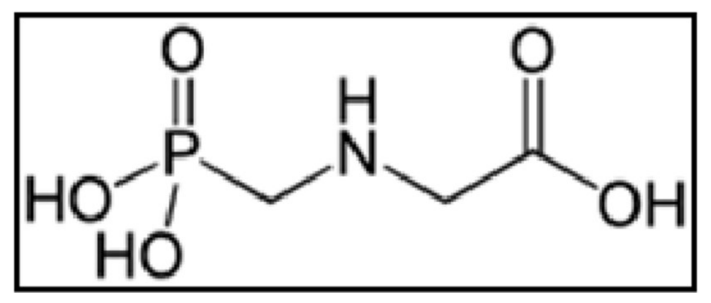

Source: DUKE; POWLES (2008).

The compound is effective for the elimination of weeds and in the development of genetically modified varieties of soybean, cotton, canola, and corn (Annett et al. 2014). The mode of action of glyphosate is unique, because it targets the synthesis of 5-enolpiruvilshiquimate-3-phosphate (EPSPS), which results in the inhibition of aromatic amino acid biosynthesis in the shiquimate pathway, damaging the synthesis of proteins and secondary metabolites and affecting the vital energy pathways in plants and soil microorganisms 
(BOOCOCK; COGGINS, 1983). However, the glyphosate is considered the most effective herbicide compared to others, extensive and large-scale use causes its accumulation in the environment and in edible products, generating negative consequences for the environment and humans (WANG et al. 2016; ZHAN et al. 2018).

In the environment, glyphosate binds to soil particles and accumulates in the topsoil, where it can cause structural damage and changes in microbial communities, inhibiting the growth of microorganisms and facilitating the proliferation of phytopathogenic fungi. Therefore, glyphosate is often detected in groundwaters and surface waters and aquatic sediments from surface runoff and vertical transport in the soil (ZHAN et al. 2018). However, in human health, glyphosate residues have never exceeded the limit established by legislation, but its negative effects cannot be ruled out. There is evidence that this herbicide contains carcinogenic contaminants that cause organ damage through oxidative stress and acetylcholinesterase inhibition (MESNAGE et al. 2015).

Over the past few years, studies about glyphosate toxicity have become the focus of various researches, and bioassay are useful tools to estimative damage caused by toxic pollutants in terrestrial and aquatic environments. Particularly, phytotoxicity tests which use plants and/or vegetables, are indicated for having some advantages, such as simplicity, reliability, fast results, and low cost. The lettuce species Lactuca sativa, is one of the most used for this type of tests because it demonstrates greater sensitivity to environmental stress than other organisms. In addition, it is among the 10 plant species recommended as indicators in toxicological studies by the United States Environmental Protection Agency and the Organization for Economic Development and Cooperation to determination the ecological effects of toxic substances (MAGDALENO et al. 2015). Therefore, this study evaluated the phytotoxicity of agrochemical solutions glyphosate in different concentrations for the lettuce species Lactuca sativa Buttercrunch, using as main parameters the number of germinated seeds and the growth of the stem and root.

\section{Material and Methods}

\subsection{Toxicological Test}


This study was conducted at the water and waste treatment laboratory of the Agroveterinary Science Center, Brazil. The determination of the glyphosate phytotoxicity was carried out by applying the test with Lactuca sativa lettuce seeds, which followed the procedures described in the United States Environmental Protection Agency (USEPA, 1996), a method called "Seed Germination / Root Elongation Toxicity Test". Five Petri dishes with filter paper previously sterilized in an autoclave at a pressure of $1 \mathrm{~atm}$ and at a temperature of $120^{\circ} \mathrm{C}$ for 15 minutes, were separated for each treatment. The treatments analyzed were glyphosate solutions in concentrations of 0.001 mg.L-1; 0.1 mg.L-1; 0.5 mg.L-1; 1 mg.L-1; 20 mg.L-1 and a blank test (using distilled water to replace the sample). The concentrations were defined based on Brazilian legislation, which allows up to $0.5 \mathrm{mg}$.L-1 of glyphosate in a sample of drinking water. Thus, the study covers the maximum allowed concentration, as well as slightly higher and lower concentrations (BRASIL, 2017). To prepare the solutions, initially a Stock solution of $100 \mathrm{mg} . \mathrm{L}-1$ was prepared. For this, $0.001 \mathrm{~g}$ of glyphosate was measured on an analytical scale, which was diluted in distilled water and later transferred to a $10 \mathrm{~mL}$ volumetric flask.

First, the seeds of the Lactuca sativa Buttercrunch lettuce were immersed in $10 \%$ bleach for 20 minutes. In sequence, they were washed with distilled water 5 times, completing their treatment. In each Petri dish, five seeds of the treated lettuce were added on the germination paper (filter paper). Immediately, $2 \mathrm{~mL}$ of the sample was added over the seeds. The plates were wrapped in plastic in order to minimize the loss of moisture and were introduced in a dark environment and controlled temperature at $23^{\circ} \mathrm{C}$, where they were kept for a period of 5 days.

\subsection{Statistical Analysis}

For the statistical analysis of the phytotoxicity test, the number of germinated seeds in each treatment was counted and the length of the roots and stem of each germinated seed was measured using an analog caliper as performed by Gryczak et al. (2018). The variables mentioned above were included in equations for the definition of the percentage parameters of Germination Effect (\%GE), Root Growth Inhibition (\%RGI) and Germination 
Index (\%GI), as shown in Equations 1, 2 and 3, respectively. Such equations were used in the study developed by Göde et al. (2019). The results obtained were subjected to analysis of variance (ANOVA) and compared using the Tukey test at the $5 \%$ level of significance.

$$
\begin{aligned}
& \% G E=\frac{N G S}{T N S} \times 100 \\
& \% R G I=\frac{A R G C-A G S R}{A R G C} \times 100 \\
& \% G I=\frac{L S R \times N G S S}{R L C \times N G S C} \times 100
\end{aligned}
$$

Where,

\%GE is the germination effect, given in percentage;

NGS is the number of germinated seeds, given in units;

TNS is the total number of seeds, given in units;

$\% R G I$ is the root growth inhibition, given as a percentage;

$A R G C$ is the average root growth of the control group, given in centimeters;

AGSR is the average growth of the sample root, given in centimeters;

$\% \mathrm{Gl}$ is the germination index, given in percentage;

LSR is the length of the sample root, given in centimeters;

NGSS is the number of germinated seeds in the sample, given in units;

$\mathrm{RLC}$ is the root length of the control group, given in centimeters; and

NGSC is the number of germinated seeds in the control group, given in units.

\section{Results and Discussion}

The results obtained regarding the number of germinated seeds and the length of the root and stem in each treatment tested by the toxicity test in solutions of different concentrations of the agrochemical glyphosate can be seen in Table 1.

Table 1 - Results of the toxicity test with lettuce L. sativa 
Number of germinated seeds
Stem length $(\mathrm{cm})$
MEAN

$(\bar{x})$
MEAN

$(\bar{x})$

\begin{tabular}{|c|c|c|c|c|c|c|c|c|c|c|c|c|c|}
\hline \multirow{5}{*}{$0,001 \mathrm{mg} \cdot \mathrm{L}^{-1}$} & 5 & 3 & 2,1 & 2,8 & 1,8 & 2 & 2,34 & 3,1 & 3,6 & 3,5 & 2,4 & 3 & 3,12 \\
\hline & 5 & 3,6 & 2,1 & 1,5 & 3,6 & 0,1 & 2,18 & 4,1 & 2,8 & 1,5 & 3,1 & 0 & 2,30 \\
\hline & 5 & 1,7 & 2,3 & 2 & 1,8 & 2,5 & 2,06 & 1,5 & 3,7 & 3,3 & 1,3 & 3,9 & 2,74 \\
\hline & 4 & 2,8 & 2,7 & 2 & 2,3 & - & 2,45 & 3,3 & 2,4 & 2,7 & 2,3 & - & 2,68 \\
\hline & 4 & 2,4 & 1,6 & 1,2 & 0,1 & - & 1,325 & 2,7 & 2 & 2,1 & 0 & - & 1,70 \\
\hline $\bar{x}$ & 4,6 & & & & & & 2,071 & & & & & & 2,51 \\
\hline \multirow{5}{*}{$0,1 \mathrm{mg} \cdot \mathrm{L}^{-1}$} & 4 & 2 & 1,9 & 2,5 & 0,9 & - & 1,825 & 2,2 & 1,9 & 2,2 & 2,9 & - & 2,30 \\
\hline & 5 & 1,8 & 2,2 & 2,6 & 2,3 & 1,8 & 2,14 & 2,3 & 3,1 & 3,5 & 3 & 2,3 & 2,84 \\
\hline & 5 & 2,5 & 2,9 & 1,2 & 0,9 & 0,3 & 1,56 & 2,5 & 3,7 & 0 & 0,6 & 0,2 & 1,40 \\
\hline & 5 & 1,9 & 2,2 & 1,3 & 2 & 0,7 & 1,62 & 2 & 2,8 & 1,4 & 2 & 0 & 1,64 \\
\hline & 5 & 2,3 & 1,3 & 1,8 & 2,2 & 0,7 & 1,66 & 4 & 3 & 2,8 & 2,5 & 0,1 & 2,48 \\
\hline$\overline{\bar{x}}$ & 4,8 & & & & & & 1,761 & & & & & & 2,13 \\
\hline \multirow{5}{*}{$0,5 \mathrm{mg} \cdot \mathrm{L}^{-1}$} & 5 & 2,8 & 2,1 & 2,3 & 1,1 & 0,7 & 1,8 & 3 & 3 & 2,4 & 0,5 & 0,2 & 1,82 \\
\hline & 4 & 3,2 & 2,5 & 3,2 & 2,6 & - & 2,875 & 3,4 & 2,6 & 3,1 & 3,6 & - & 3,18 \\
\hline & 5 & 1,7 & 1,9 & 1,6 & 1,8 & 2 & 1,8 & 2,5 & 2,9 & 2,8 & 1,6 & 2,5 & 2,78 \\
\hline & 5 & 2,1 & 2,3 & 2,1 & 2,2 & 2,3 & 2,2 & 2,9 & 2,6 & 2,9 & 2,7 & 2,3 & 2,57 \\
\hline & 5 & 2,9 & 3,1 & 0,7 & 0,6 & 0,5 & 1,56 & 3,2 & 3,3 & 0,2 & 0,7 & 0,2 & 2,10 \\
\hline $\bar{x}$ & 4,8 & & & & & & 2,047 & & & & & & 2,49 \\
\hline \multirow{5}{*}{$1 \mathrm{mg} \cdot \mathrm{L}^{-1}$} & 5 & 2,4 & 2,8 & 2,4 & 1,6 & 1 & 2,04 & 2,6 & 3,3 & 3,5 & 1 & 0,8 & 1,88 \\
\hline & 5 & 1,5 & 2,1 & 2,7 & 1,8 & 0,6 & 1,74 & 0,1 & 3,2 & 3,2 & 1,8 & 0,4 & 1,99 \\
\hline & 4 & 2,2 & 2,5 & 2,1 & 1,4 & - & 2,05 & 2,3 & 1,6 & 1,9 & 2,8 & - & 2,15 \\
\hline & 5 & 2,6 & 2,4 & 2,5 & 1,9 & 0,3 & 1,94 & 4,1 & 2,4 & 3 & 3,1 & 0 & 2,52 \\
\hline & 4 & 2,9 & 2,6 & 3,3 & 1,3 & - & 2,525 & 3,3 & 2,2 & 4,3 & 2,3 & - & 3,03 \\
\hline $\bar{x}$ & 4,6 & & & & & & 2,059 & & & & & & 2,31 \\
\hline \multirow{5}{*}{$20 \mathrm{mg} \cdot \mathrm{L}^{-1}$} & 4 & 2,7 & 1,6 & 3,3 & 0,9 & - & 2,125 & 1,2 & 0,1 & 1,2 & 0 & - & 0,63 \\
\hline & 5 & 2,7 & 2,9 & 1,3 & 2,2 & 1 & 2,02 & 1,1 & 1,1 & 0,1 & 0,7 & 0,1 & 0,62 \\
\hline & 4 & 3,1 & 1,6 & 2,8 & 0,2 & - & 1,925 & 1,5 & 0,8 & 1,3 & 0,1 & - & 0,93 \\
\hline & 4 & 1,5 & 2,2 & 2,2 & 2 & - & 1,975 & 0,7 & 1,1 & 1,3 & 1,1 & - & 1,05 \\
\hline & 5 & 2,1 & 1,9 & 2,2 & 0,4 & 0,6 & 1,44 & 0,9 & 1 & 0,9 & 0 & 0 & 0,56 \\
\hline $\bar{x}$ & 4,4 & & & & & & 1,897 & & & & & & 0,76 \\
\hline \multirow{5}{*}{ Blank } & 4 & 2,4 & 2,4 & 0,1 & 0,1 & - & 1,25 & 2,3 & 3 & 0,6 & 0,1 & - & 1,50 \\
\hline & 4 & 2,1 & 2,5 & 2,4 & 1,4 & - & 2,1 & 3,8 & 3 & 3,6 & 1,3 & - & 2,93 \\
\hline & 5 & 1,7 & 1,7 & 2 & 1,5 & 1,5 & 1,68 & 1,3 & 1 & 2,6 & 0,9 & 1,8 & 1,52 \\
\hline & 4 & 3,4 & 1,6 & 2 & 0,1 & - & 1,775 & 3,7 & 2,3 & 2,2 & 0 & - & 2,05 \\
\hline & 5 & 2,3 & 2,4 & 2,5 & 0,7 & 0,5 & 1,68 & 3 & 2,7 & 3,1 & 1,7 & 0,1 & 2,12 \\
\hline $\bar{x}$ & 4,4 & & & & & & 1,697 & & & & & & 2,02 \\
\hline
\end{tabular}

Source: The authors (2020).

The results obtained by the application of the data observed in the toxicity test in Equations 1, 2 and 3 are described in Table 2. 
Table 2 - Germination effect, inhibition of root growth and germination index of the analyzed treatments

\begin{tabular}{lcccccc}
\hline & Blank & $\mathbf{0 , 0 0 1} \mathbf{~} \mathbf{~ g} \cdot \mathbf{L}^{-\mathbf{1}}$ & $\mathbf{0 , 1} \mathbf{~} \mathbf{~ g} \cdot \mathbf{L}^{-\mathbf{1}}$ & $\mathbf{0 , 5} \mathbf{~} \mathbf{~ g} \cdot \mathbf{L}^{-\mathbf{1}}$ & $\mathbf{1} \mathbf{~} \mathbf{~ g} \cdot \mathbf{L}^{-\mathbf{1}}$ & $\mathbf{2 0} \mathbf{~} \mathbf{~ g} \cdot \mathbf{L}^{-\mathbf{1}}$ \\
\hline Germination Effect (\%GE) & 0,88 & 0,92 & 0,96 & 0,96 & 0,92 & 0,88 \\
Root Growth Inhibition (\%RGI) & 0,0 & $-23,92$ & $-5,38$ & $-23,01$ & $-14,33$ & 62,62 \\
Germination index (\%Gl) & 1,0 & 1,29 & 1,14 & 1,34 & 1,19 & 0,37 \\
\hline
\end{tabular}

Source: The authors (2020).

Through the analysis of Tables 1 and 2, it is highlighted that the concentration of 20 mg.L-1 of the glyphosate solution was more toxic for lettuce L. sativa, compared to the others groups tested, as it showed a notorious root growth inhibition value and resulted in the lowest germination index. Apparently, the lowest concentrations analyzed are not harmful to plant growth, which can be ascertained through the application of statistical tests. A similar response was observed for lettuce (Lactuca sativa), tomato (Lycopersicon esculentum) and cucumber (Cucumis sativus), where the concentration of $18 \mathrm{mg} . \mathrm{L}-1$ of glyphosate proved to be toxic and inhibited the root growth of species (DE BRITO RODRIGUES et al. 2017). There are few studies on the phytotoxicity of glyphosate to lettuce, however, there is a large amount of research carried out with other organisms. Sikorski et al. (2019), reported that the accumulation of glyphosate in plant tissues had toxic effects on common duckweed (Lemna minor), slowing down its growth and production, as well as inhibition the synthesis of chlorophyll $a$ and b carotenoids. In contrast to the previously mentioned in situ tests, studies carried out with the application of the herbicide glyphosate in different plants in field tests, elucidated a high gradient of sensitivity of the plants to the herbicide, where there was a decrease in growth as the glyphosate concentration increased, causing even the mortality of some species (PFLEEGER et al. 2012; FLORENCIA et al. 2017). Gazola et al. (2016), when investigating the potential of the herbicide for application in grass for an esthetic purposes, showed that glyphosate can be used as a growth regulator, because it inhibited the synthesis of the enzyme 5-enolpyruvylshiquimate-3-phosphate that promotes plant growth and development. Glyphosate is the most widely used herbicide for 
weed control, however it has toxic effects on plant growth, as its mode of action occurs through the synthesis of the enzyme 5-enolpyruvylshiquimate-3-phosphate (EPSP) synthase (EC 2.5.1.19) that promotes growth and results in the inhibition of aromatic amino acid biosynthesis in the shiquimate pathway (BOOCOCK; COGGINS, 1983; ROSE et al. 2018). The results obtained by the ANOVA tests can be seen in Table 3. 
Table 3 - Results of ANOVA tests

\begin{tabular}{lcccccc}
\hline \multicolumn{7}{c}{ Number of Germinated Seeds } \\
\hline Variation source & SQ & gl & MQ & $F$ & value-P & F critical \\
Between groups & 0,8 & 5 & 0,1600 & 0,6000 & 0,7003 & 2,6207 \\
Within groups & 6,4 & 24 & 0,2667 & & & \\
\hline & & Stem Lenght & & & \\
\hline Variation source & SQ & gl & MQ & $F$ & value-P & F critical \\
Between groups & 0,6688 & 5 & 0,1338 & 1,0505 & 0,4116 & 2,6207 \\
Within groups & 3,0562 & 24 & 0,1273 & & & \\
\hline & & Root Lenght & & & \\
\hline Variation source & SQ & gl & MQ & $F$ & value-P & F critical \\
Between groups & 10,7558 & 5 & 2,1512 & 8,3977 & 0,0001 & 2,6207 \\
Within groups & 6,1478 & 24 & 0,2562 & & & \\
\hline
\end{tabular}

Source: The authors (2020).

For the variables "number of germinated seeds" and "stem length", the calculated F value was less than the critical $F$ value, and the $P$ value was greater than 0.05 , which means that there are no statistically significant differences between the groups evaluated (glyphosate solutions in concentrations of 0,001 mg.L-1 0,1 mg.L-1, 0,5 mg.L-1, 1 mg.L-1, 20 mg.L-1 and the blank) at a significance level of 5\%. However, for the variable "root length", the statistical results showed an opposite result, with $\mathrm{F}$ greater than critical $\mathrm{F}$ and $\mathrm{P}$ value less than 0,05 , it is concluded that there is a significant difference between groups of different concentrations of glyphosate solutions. For the identification of groups that differ from each other, the Tukey test was applied. The results can be seen in Table 4, where equal letters mean that there is no significant difference between the groups, and different letters mean that there is a significant difference, at a $5 \%$ significance level. 
Table 4 - Results of Tukey test

\begin{tabular}{lcccccc}
\hline \multicolumn{7}{c}{ Root Lenght } \\
\hline Glyphosate concentration $\left(\mathrm{mg} \cdot \mathrm{L}^{-1}\right)$ & 0,001 & 0,1 & 0,5 & 1 & 20 & Blank \\
0,001 & - & & & & & \\
0,1 & a & - & & & & \\
0,5 & a & a & - & & & \\
1,0 & a & a & a & - & & \\
20 & b & b & b & b & - & \\
Blank & a & a & a & a & b & - \\
\hline
\end{tabular}

Source: The authors (2020).

The Tukey test revealed that only the highest concentration of glyphosate tested (20 mg.L-1) differed from all other groups for the variable "root growth", that is, the lowest concentrations tested do not have significant differences in relation to blank, therefore, they were not toxic to the growth of the roots of the lettuce L. sativa Buttercrunch. Analyzing the graphs in Figure 4, it can be seen that only high concentrations of glyphosate were toxic to the growth of the lettuce used in the tests, given that it is in accordance with the indexes obtained in Table 2. According to the norms stablished by the Brazilian legislation, the use of glyphosate is allowed in a concentration up to $0,5 \mathrm{mg}$.L-1 in a sample of drinking water (BRASIL, 2017), unlike the USA, which allows the concentration of $0,7 \mathrm{mg} \cdot \mathrm{L}-1$ as the maximum level of contaminant $(M D H, 2017)$. Glyphosate when below permitted concentrations has low toxicity to organisms and has limited harmful effects or none. In human health, the risks that this herbicide may cause are associated with signs of oxidative stress, liver and kidney damage, when ingested a concentration greater than 0,3 to 0,5 mg.Kg-1 body weight day -1, a value regulated by German Federal Risk Assessment Institute (MEFTAUL et al. 2020; MESNAGE et al. 2015). 


\section{Conclusion}

With the highest percentage of root growth inhibition and the lowest germination index, the glyphosate solution with a concentration of $20 \mathrm{mg} . \mathrm{L}-1$ stood out in terms of lettuce L. sativa Buttercrunch toxicity. In addition, it was the only concentration that statistically differed significantly from the other groups evaluated, including the control group (blank), for the variable "root length". For future works in this area, it is recommended that glyphosate cytotoxicity and genotoxicity are determined, in order to enhance the collection on the toxic effects of this pesticide on different aspects and organisms. The understanding of the toxicity that chemicals and agrochemicals represent for the ecosystem and for human health it is the great of paramount importance for the preservation of the human right of conscious choice about the type of food that he prefers to consume.

\section{Acknowledgments}

The authors are grateful to the Water and Waste Treatment Laboratory (LabTrat) from Agroveterinary Science Center of the State University of Santa Catarina (CAV/UDESC) for the support and technical guidance during the experimentation carried out. This survey did not receive any specific grant awards from public, commercial, or non-profit sectors.

\section{References}

ABDELHAMEED, R.M.; EL-ZAWAHRY, M.; EMAM, H.E.; 2018. Efficient removal of organophosphorus pesticides from wastewater using polyethylenimine-modified fabrics. Polymer, v. 155, p. 225-234.

AKTAR, W.; SENGUPTA, D.; CHOWDHURY, A; 2009. Impact of pesticides use in agriculture: their benefits and hazards. Interdisciplinary Toxicology, v. 2(1), p. 1-12.

ANNETT, R.; HABIBI, H. R.; HONTELA, A; 2014. Impact of glyphosate and glyphosate-based herbicides on the freshwater environment. Journal of Applied Toxicology, v. 34(5), p. 458479.

BOOCOCK, M. R.; COGGINS, J. R; 1983. Kinetics of 5-enolpyruvylshikimate-3-phosphate synthase inhibition by glyphosate. FEBS Letters, v. 154(1), p. 127-133. 
BRASIL; 2017. Portaria de Consolidação n5 de 28 de setembro de 2017. Ministério da Saúde, p. 1-926.

DE BRITO RODRIGUES, L.; DE OLIVEIRA, R.; ABE, F.R.; BRITO, L.B.; MOURA, D.S.; Valadares, M.C.; Grisolla, C.K., De Oliveira, D.P.; De Oliveira, G.A.R.; 2017. Ecotoxicological assessment of glyphosate-based herbicides: Effects on different organisms. Environmental Toxicology and Chemistry, v. 36 (7), p. 1755-1763.

DEBNATH, D.; GUPTA, A. K.; GHOSAL, P. S; 2019. Recent advances in the development of tailored functional materials for the treatment of pesticides in aqueous media: A review. Journal of Industrial and Engineering Chemistry, v. 70, p. 51-69.

DUKE, S. O.; POWLES, S. B; 2008. Glyphosate: a once-in-a-century herbicide. Pest Management Science, v. 64(4), p. 319-325.

FLORENCIA, M.F.; TORRES, C.; BRACAMONTE, E.; GALETTO, L.; 2017. Effects of the herbicide glyphosate on non-target plant native species from Chaco forest (Argentina). Ecotoxicology and Environmental Safety, v. 144, p. 360-368.

GAZOLA, R.P.D.; BUZETTI, S.; GAZOLA, R.N.; DE CASTILHO, R.M.M.; FILHO, M.C.M.T.; CELESTRINO, T.S.; DUPAS, E.; 2016. Nitrogen dose and type of herbicide used for growth regulation on the green coloration intensity of Emerald grass. Ciência Rural, v. 46 (6), p. 984990.

GÖDE, J. N.; SOUZA, D. H.; TREVISAN, V.; SKORONSKI, E.; 2019. Application of the Fenton and Fenton-like processes in the landfill leachate tertiary treatment. Journal of environmental Chemical Engineering, v. 7, p. 1-8.

GRYCZAK, M.; KILIPPER, J. T.; COSTA, P. D. DE; MACCARI, A.; 2018. Sementes de Lactuca Sativa como bioindicador de toxicidade em resíduos de construção civil. Revista Tecnologia e Ambiente, v. 24, p. 233-242.

KONSTANTINOU, I. K.; HELA, D. G.; ALBANIS, T. A.; 2006. The status of pesticide pollution in surface waters (rivers and lakes) of Greece. Part I. Review on occurrence and levels. Environmental Pollution, v. 141(3), p. 555-570.

MAGDALENO, A.; PERALTA GAVENSKY, M.; FASSIANO, A. V.; RÍOS DE MOLINA, M. C.; SANTOS, M.; MARCH, H.; MORETTON, J.; JUÁREZ, Á. B.; 2015. Phytotoxicity and genotoxicity assessment of imazethapyr herbicide using a battery of bioassays. Environmental Science and Pollution Research, v. 22(23), p. 19194-19202.

MAURYA, P.; YADAV, L.; 2014. Uses of pesticide in foods: Curse for health. Asian Journal of Bio Science, v. 9(1), p. 123-128.

MDH; 2017. Glyphosate and Drinking Water. Minnesota Department of Health, October, p.12. 
MEFTAUL, I.M.; VENKATESWARLU, K.; DHARMARAJAN, R.; ANNAMALAI, P.; ASADUZZAMAN, M.; PARVEN, A.; MEGHARAJ, M.; 2020. Controversies over human health and ecological impacts of glyphosate: Is it to be banned in modern agriculture? Environmental Pollution, v. 263, p. 114372.

MESNAGE, R.; DEFARGE, N.; SPIROUX DE VENDÔMOIS, J.; SÉRALINI, G. E.; 2015. Potential toxic effects of glyphosate and its commercial formulations below regulatory limits. Food and Chemical Toxicology, v. 84, p. 133-153.

MORAES, R.F.DE.; 2019. Agrotóxicos no Brasil: padrões de uso, política da regulação e prevenção da captura regulatória. Instituto de Pesquisa Econômica Aplicada, p. 84.

PFLEEGER, T.; BLAKELEY-SMITH, M.; KING, G.; LEE, E.H.; PLOCHER, M.; OLSZYK, D.; 2012. The effects of glyphosate and aminopyralid on a multi-species plant field trial. Ecotoxicology, $\mathrm{v}$. 21 (7), p. 1771-1787.

QI, H.; HUANG, Q.; HUNG, Y.-C.; 2018. Effectiveness of electrolyzed oxidizing water treatment in removing pesticide residues and its effect on produce quality. Food Chemistry, Elsevier Ltd, v. 239, p. 561-568.

ROSE, T.J.; ZWIETEN, L.V.; CLAASSENS, A.; SCANLAN, C.; ROSE, M.T.; 2018. Phytotoxicity of soilborne glyphosate residues is influenced by the method of phosphorus fertiliser application. Plant and Soil, v. 422 (1-2), p. 455-465.

SIKORSKI, L.; BACIAK, M.; BES, A.; ADOMAS, B.; 2019. The effects of glyphosate-based herbicide formulations on Lemna minor, a non-target species. Aquatic Toxicology, v. 209, p. 70-80.

USEPA; 1996. Ecological effects test guidelines earthworm subchronic toxicity Test. United States Environmental Protection Agency, April, p. 1-11.

WANG, S.; SEIWERT, B.; KÄSTNER, M.; MILTNER, A.; SCHÄFFER, A.; REEMTSMA, T.; YANG, Q.; NOWAK, K. M.; 2016. (Bio)degradation of glyphosate in water-sediment microcosms - A stable isotope co-labeling approach. Water Research, v. 99, p. 91-100.

ZHAN, H.; FENG, Y.; FAN, X.; CHEN, S.; 2018. Recent advances in glyphosate biodegradation. Applied Microbiology and Biotechnology, v. 102(12), p. 5033-5043.

ZHANG, J.-W.; XU, D.-Q.; FENG, X.-Z.; 2019. The toxic effects and possible mechanisms of glyphosate on mouse oocytes. Chemosphere, Elsevier Ltd, v. 237, p. 1-10. 